Article

\title{
"Every Living Beast Being a Word, Every Kind Being a Sentence": Animals and Religion in Reformation Europe
}

\author{
Helen Parish \\ Department of History, University of Reading, Reading RG6 6AH, UK; h.l.parish@reading.ac.uk
}

Received: 1 May 2019; Accepted: 25 June 2019; Published: 9 July 2019

\begin{abstract}
The ability of animals to convey meaning, either sacred or profane, features prominently in the dialectic of natural knowledge and sacred histories. Animals, particularly those that exhibited irregularities of nature, symbolised and revealed God's wrath and favour, fulfilling a polemical and pastoral purpose in the communication of God's anger and assiduous care for humanity. The language of readable nature ran through the ancient natural histories of Pliny and Aristotle, the words and images of the medieval bestiaries, and the natural histories and popular discourses of Reformation Europe. In the history of the natural world, 'God's great book in folio', ideas about connections between the written word and human observation, miracles, wonders and providences, were interleaved with theological and biological taxonomies. In so doing, discussions of irregularities and portents in nature expose the conceptualisation of human relationships with the world, with the past, with the present, and with the divine. This article explores the connections between real and symbolic animals, religious, and the plasticity of God's creation in the natural histories and polemical literature of the Reformation. It explores the multivalent positioning of particular sea creatures as providential signs of God's continued presence in the world, natural phenomena, and man-made objects, and the ongoing syncretism between natural history, religion, ancient texts and human observation in the dialectic of this period.
\end{abstract}

Keywords: animals; sea creatures; natural history; providence; reformation

\section{Introduction}

Now the Lond had prepared a great fish to swallow up Jonah. And Jonah was in the belly of the fish three days and three nights. Then Jonah prayed unto the LorD his God out of the fish's belly, and said, I cried by reason of mine affliction unto the LoRD, and he heard me; out of the belly of hell cried I, and thou heardest my voice. For thou hadst cast me into the deep, in the midst of the seas; and the floods compassed me about: all thy billows and thy waves passed over me. Then I said, I am cast out of thy sight; yet I will look again toward thy holy temple. The waters compassed me about, even to the soul: the depth closed me round about, the weeds were wrapped about my head. I went down to the bottoms of the mountains; the earth with her bars was about me for ever: yet hast thou brought up my life from corruption, O LoRD my God. When my soul fainted within me I remembered the LorD: and my prayer came in unto thee, into thine holy temple. They that observe lying vanities forsake their own mercy. But I will sacrifice unto thee with the voice of thanksgiving; I will pay that that I have vowed. Salvation is of the Lord. And the Lord spake unto the fish, and it vomited out Jonah upon the dry land [Jonah 1:17-2:10].

Jonah's physical journey to Nineveh in the belly of the dag gadol (דג גדול, great fish), and spiritual journey from lying vanities to redemption served to establish within the Judaeo-Christian tradition a model of God's providential interventions in the affairs of man, and the role of animals and fish as 
a vehicle within this model. Rhetorical and religious language presented flora, fauna, insects, and fish as the embodiment and enactors of the will of God, and imbued irregularities and anomalies in nature with a potent theological significance. Animals have been described as a 'necessary part of our reconceptualization of ourselves as human' (Fudge 2000; 2002, pp. 6-7), providing a compelling thread running through the history of humanity's relationships with the divine. The ability of animals to convey meaning, either sacred or profane, features prominently in the dialectic of natural knowledge and sacred histories. Any investigation of the ways in which humans have understood animals prioritises the human voice and text over the narrative of the non-human, but also illuminates the extent to which animals were positioned and perceived as a conduit for religious messages and metaphors. Animals, particularly those that exhibited irregularities of nature, symbolised and revealed God's wrath and favour, fulfilling a polemical and pastoral purpose in the communication of God's anger and assiduous care for humanity. The language of readable nature ran through the ancient natural histories of Pliny and Aristotle, the words and images of the medieval bestiaries, and the natural histories and popular discourses of Reformation Europe. In the history of the natural world, 'God's great book in folio', ideas about connections between the written word and human observation, miracles, wonders and providences, were interleaved with theological and biological taxonomies. In so doing, discussions of irregularities and portents in nature expose the conceptualisation of human relationships with the world, with the past, with the present, and with the divine (Fudge 2002; Walsham 1999, 2011; Thomas 1983; Clair 1967; Flore 2000; Smith 1980).

Detailed interrogation of the structures of early modern natural history is a relatively new phenomenon, although one that has been swift to develop a momentum. Individual authors such as Gesner, Aldrovandi and Ray punctuated older narratives of the emergence of science in this period, but active reflection upon the motives and purposes that underpinned natural history acquired a cumulative force in the final two decades of the twentieth century. As a result, the assumptions that underpinned the biographical approach to the subject have been largely superceded by a more nuanced analysis that engages with questions around the intersection of old and new, the form and function of religious language in natural histories, material culture and collecting, social and cultural networks and exchanges, and the relationship between natural history and human history (Findlen 1994; Pinon 1995; Jardine et al. 1996; Daston and Park 1998).

It is worth pausing here to consider the very use of the term 'historia' in the discussion of natural history. Gianni Pomata and Nancy Siraisi provide us ample encouragement to do so by locating natural history within the broader context of a scholarship and methodology that prioritised the collection and reporting of information. The evolution of the meaning of 'historia' between the fifteenth and eighteenth centuries emerged from an energetic focus on explanation rather than narrative, and the presentation of direct and mediated eye-witness and personal experience alongside authoritative written sources. Laurent Pinon's analysis of Gesner's work, for example, explores both the breadth and depth of its historical approach, demonstrating Gesner's desire to provide his reader with an account that was informed by that which he had seen and heard, and by that which he had read. In such an approach, it is possible to perceive evidence of a diminished sense of the pre-eminence of the textual over the verbal, and emergence of a more ambitious and polyvalent approach to the writing of history. But throughout this period, the history of humanity and the history of nature continued to be constructed around shared assumptions that were not so much destroyed as over-written, and not entirely divorced from the allegorical interpretations and supernatural interventions that had permeated medieval bestiaries. For this reason, an approach to the texts that recognises a plurality in histories of nature, rather than a single tradition, is essential. Such a recognition acknowledges the permeability of the boundary between nature and culture, and the extent to which the distinctiveness and diversity of early modern natural histories emerged from cross-fertilisation across this boundary. Detailed descriptions of nature in this period did not lose contact with that sense of the past, but rather grew out of, and required, a deeply rooted sense of the historical and philological reading of the natural 
world (Pomata and Siraisi 2005, introduction; Mulsow 2005; Pinon 2005; Kelly 1997; Muller-Wille and Charmantier 2012).

That same cross-fertilisation enabled and encouraged the continued use of ancient authorities by those who shaped the historia naturalis of the sixteenth and seventeenth centuries. In so doing, they exposed the extent to which the challenges presented by the relationship between old and new, nature and humanity, were just as visible in those ancient texts. Pliny, describing his intentions when composing the Natural History, pondered the challenge of 'giving novelty to what is old, authority to what is new, brilliance to the commonplace, light to the obscure, attraction to the stale, credibility to the doubtful.' (Rackham 1967, pp. 9-11). That careful juxtaposition of old and new, visible and invisible, was equally evident in the natural histories compiled in Renaissance and Renaissance and early modern Europe, histories in which the method, language, and encylopaedic content of Pliny's work loomed large. As Sarah Blake McHam has observed, the ways in which Pliny was read and used in this period present a clear and illuminating illustration of the ways in which tradition and reality combined in the thought and practice of the age (McHam 2013). Plundered for information, the Natural History continued to be exploited for its moralised and instructive reading of the natural world. Likewise, the 'historia' of Herodotus encompassed both the human and the natural world, and its acceptance of the didactic purpose of history was not limited to the human past alone. This moralised approach to nature that had shaped the content of the medieval bestiaries certainly did not disappear entirely in the early modern period. The understanding of what might be considered 'regular' in the physical appearance of nature remained broadly consistent, and firmly rooted in the classical texts, notably Pliny's Natural History (Rackham 1967, Book 3 c.11). Where there was a significant change in attitudes to the unnatural, it grew out of a cross-pollination of traditional medieval narratives of the monstrous and a distinctive post-reformation view of irregularities of nature as indicative and reflective of the religious, social, and moral failings of the age. The shift that occurred in the writing of nature had much less to do with the demise of its function as a repository of moral exempla, and much more to do with the desire to ensure that this repository presented as accurate and meaningful a picture of the natural world as was possible (Ogilvie 2005; Brammall 1996).

Brian Ogilvie's bold assertion that 'natural history was invented in the Renaissance' has fuelled a more energetic and thoughtful approach to the reading and writing of nature in the early modern period, and one that recognises both continuity and change in this period (Ogilvie 2006, p. 1). The driving force behind Ogilvie's seminal The Science of Describing was the study of botany and the separation of natural philosophy and medicine in this period, but the language of 'invention' here carries a conceptual force that extends beyond this emerging dichotomy. At a practical level, Ogilvie's observation is well supported; a simple quantitative analysis of a burgeoning print culture demonstrates the creation of a myriad of new ways of presenting and describing nature. But was the content and effect of this expanding genre transformative? In the short term, the answer surely has to be more measured in its assessment. Recent scholarship has mined effectively the complex intersections of continuity and change in the reading of the natural world in this period and at the very least, exposed the real danger in reading back into early modern science, or natural history, that which we would hope to find within it. Ogilvie is swift to perceive the challenge here, suggesting that historians searching for evidence of the precursors of modern biological sciences in the natural histories of the Renaissance have been blinded to the real innovations of the age. Early modern natural histories were works of compilation, not a systematic effort to classify and define. The guiding principle was to not to explain but to describe, not to distinguish and compartmentalise, but to gather together. If such endeavours were to inform the development of more robust taxonomic approaches, this occurred as the result of a decontextualization of knowledge, by its gradual rather than immediate removal from its local context (Ogilvie 2006).

In a similar vein, Stephen Jay Gould's discussion of the work and world of Athanius Kircher makes a concerted and convincing attempt to undermine any notion of Whiggish progress, utilising the same kind of language that is deployed to good effect in Walsham's assault on the Weberian notion of 'disenchantment' in early modern Europe. Likewise, Nancy Siraisi and Gianni Pomata's discussion 
of empiricism and erudition in early modern Europe reminds its readers on more than one occasion that there is a danger in assuming that the early modern understanding and idea of nature is identical to that of the modern age (Gould 2004, pp. 216-18; Walsham 1999, 2011; Pomata and Siraisi 2005, p. 6; Daston and Park 1998; Daston 2017). Rather than searching for the moment at which the perception of nature and God's role within it changed, we are invited, rightly, to focus upon the less rigid and more illuminating question of how a complex and multivalent process of change came about. As Dal Prete observes, the experimental science of the seventeenth century did not reject the Aristotelianism of the Renaissance out of hand, but rather incorporated key elements into its own narratives (Dal Prete 2014, p. 316). Dal Prete's primary focus is early modern meteorology, but the basic assertion of the existence of an intellectual approach that was informed by syncretism rather than iconoclasm can and should be recognised in the discussion of natural histories. The value of such an approach has been well demonstrated in recent work on the intersections between concepts of sacred space, providentialism, and the natural world. Alexandra Walsham's seminal The Reformation of the Landscape, for example, encourages us to see evidence of mutation rather than destruction in post-reformation perceptions of a natural world that continued to manifest spiritual and emblematic meaning. Any epistemological shift from this, to a more empirical world view, was gradual and far from linear (Ashworth 1990, pp. 335-32). A medieval language in which the immanence of the holy was recognised and expected did not cease to be heard in the sixteenth and seventeenth centuries. Natural philosophy and Protestant providentialism were not mutually exclusive interpretative lenses; indeed, the study and observation of the natural world was a multi-faceted act, and one that retained much of its religious language and motive (Field and James 1997).

The importance of authorial voice, and the context that shaped it, in interpreting early modern natural history is well recognised (Dal Prete 2014, p. 293; Azzolini 2017, p. 299ff). Gesner's detailed and descriptive Historia Animalium, for example, was genuinely expansive in its approach and method, and in its aggregation of scholarship from centuries past. But it was also the product of its time, and the complex intersections between literary and cultural communities of writers and their readers, and the personal encounters of the author with the natural world that he had observed (Ogilvie 2006; Kusukawa and Maclean 2006; Azzolini 2017). Norman Jones' analysis of the early Elizabethan fascination with natural irregularities ties the buoyancy of popular print culture on the monstrous makes the same point, arguing for a clear connection between reports of 'wondrous' events and the anxieties that permeated the English mental world. This was, he notes, a period in which religious and moral beliefs were dominated by 'sheer angst.' Economic instability, political uncertainty, famine, disease and ecclesiastical reform created a situation in which the personalisation of misfortune, morality, and the consequences of sin projected onto natural irregularities a conviction that such events were intended to be relevant and focused reminders of the wrath of God and its potential consequences (Jones 1993, pp. 2-7). Only by setting early modern writing on the natural world within the specific and general cultural contexts in which it was produced can we understand the content of these histories, and unpick the story that they tell. Those who sought to describe, explain, or interpret nature were engaged in a process that was simultaneously individual and collaborative in its outworking. If the early modern description of natural history was the embodiment of centuries of wisdom and knowledge, it was also a history of nature that was anchored in personal experience, academic and social networks, and the testimony of others. That shared sense of purpose cut across not only national boundaries and confessional allegiances, but also the often artificial borders imposed upon the chronology of European natural history and philosophy (Ogilvie 2006; Azzolini 2017).

This article uses reports of wondrous, monstrous, or providential sea creatures to encourage a nuanced approach to the connections between providentialism and natural history of early modern Europe. In the case studies used, it recognises the complexity of the intersections that existed between nascent natural histories and other forms of writing about God's creation, and argues that the syncretism and juxtaposition that characterised these relationships was something to be valued, and not regarded as a sign of failure or lack of progress towards what we might see as 'modern' science and 
natural history. It argues that the detailed descriptions that attended the accounts of wondrous and preternatural events were key to their interpretation, and to the creation of a reading audience for such texts. Common threads were woven into natural and providential histories by the interposition of the personal experience of the author into the narrative, and the detailed evidence that was used to provide consistency to such texts. Recognising the persuasiveness of Ogilvie's argument that natural histories in this period demonstrated a determination to present an account of nature that was comprehensive and accurate, this article suggests that this approach be tempered by a recognition of the desire of authors whose work grew out of the interaction between animals and religion to present nature as a terrifying and malleable polemical weapon.

\section{God's Great Book in Folio: The Natural World in Protestant Providentialism}

Detailed descriptions of flora and fauna, the juxtaposition of materials old and new into an encylopaedic account, and the presentation of personal testimony and narrative within the descriptions of land and sea creatures positioned nature both as a subject worthy of study in its own right, and as an implicit and an explicit channel for the communication of the divine will. Flora, fauna, and the very geology and topography of the earth imparted a message and knowledge that was simultaneously practical, pastoral, and providential. The complex intersections that existed between natural and unnatural animals in this period are abundantly evident in discussions of unnatural sea creatures in Reformation Europe, discussions which embodied a wider confrontation between the observed marvels of the ocean, described by the cartographers and seafarers of the early modern period, and a European natural history that was refracted through the 'spectacles of scripture'. Irregularities in nature, and their ability to serve as palimpsests upon which could be laid a range of narratives and interpretations, invites careful analysis. The challenges faced in reading, seeing, describing and presenting the natural world exemplify the diversity and the common ground within the genre. Irregularities in nature were open to interpretation through the eyes of those who approached them as the building blocks of natural history, but also those for whom detailed description of the diversity of nature was part of a broader dialogue about sin and repentance, faith and anxiety, and the rhetoric of reformation. As the Protestant clergyman Edward Topsell observed, every living beast was a word or sentence in 'God's great book in folio', and it was incumbent upon both author and reader to turn the pages of that book with care (Topsell 1658, p. A5v).

This desire to read nature in order to understand God's purpose and plan for humanity fuelled the creation of a genre of providential literature intended to focus the minds of the faithful upon the dangers of human sin and its consequences. A recognition of the capacity of nature to produce wonders was clearly not new; a moralised interpretation of such events was written into almost every page of the medieval bestiary. However, as Alexandra Walsham has demonstrated with such clarity, a particularly vibrant Protestant providentialism poured from the printshops and pulpits of late sixteenth and seventeenth century England (Walsham 2000). An interest in the natural world, and its aberrations, was not the invention of the Reformation, but the potency of the connection made between such occurrences and divine wrath created an appetite for wide consumption of readily available print literature.

The discription of a rare or rather most monstrous fishe taken on the east cost of Holland the. xvii. of Nouember, anno 1566, provides a clear illustration of the type. Its subtitle made clear the message that was to be absorbed by the reader: the 'monstrous fishe' was an example of the 'the workes of God how great and straunge they be a picture plaine behold heare may you see.' The tract was written in the English vernacular, but was dominated by a detailed description of a fish that was reported to have been caught in Holland, and witnessed by most 'noble' persons of Flaunders. The author of the tract did not venture a particularly well-developed opinion as to the symbolic or actual meaning of the fish's appearance. 'What this monster with other vncouth sights sene of late do Prognosticate and signifye vnto vs' he wrote, 'I leaue to thy coniecture (louing Reader).' But the final sections of the text were rather more explicit in making the connection between such monstrous sea creatures, the sins of 
humanity, and the providential interventions of God in nature that were intended to prompt reflection and repentance. God's actions as 'gouernour of all creatures', should promote a prayerful approach for divine mercy that might avert the punishment of humanity 'according to our desertes' and enable the salvation that would come through Christ alone.

A comparison with the 1569 pamphlet, the true discription of this marueilous straunge fishe, whiche was taken on Thursday was sennight, the xvi. day of June, this present month, in the yeare of our Lord God. M.D.LX.ix (C.R. 1569) gives us a sense of the consistency and the clarity within the message of Elizabethan Protestant providentialism in print. The language and the tone of the two treatises is remarkably similar, suggesting that there was a substantial degree of stability in the form and content of the genre. Again, the lexicon was very much that of monstrosity and wonder. The appearance of the fish was 'straunge', and 'merueylous'. It had rushed into the nets of the fishermen, as if determined to be caught, with such force that the nets had torn. Again, the homiletic language implicit in the text was one of repentance, with the call to humanity to set aside sin expressed in symbol and in word in the form of the unnatural fish. The catch itself may indeed have been unusual enough to provoke comment, although the specimen described bears a marked resemblance to a thresher shark, 'round snowted, short headdid' and some seventeen feet long. One can imagine why the fishermen might have been taken by surprise by the physical size of their catch and the damage caused to their nets, although the initial shock was short-lived enough that they were prepared to consume the fish after it had been fully inspected. Here, as in other cases, the providential message in the printed narrative was a rhetorical and polemical exploitation of the events described, overlaid on a description of the sea creature that would not have been out of place in a natural history. These two pamphlets from the 1560s are relatively early examples of this kind of providential writing in English, but the framework for the genre, and its distinctive tropes, are already visible. The verbal manipulation of the tales transformed them from the status of narrative to sermon, and established a literary form that was both self-referential and self-perpetuating. Within a generation, the complexity of the imagery and interpretation was to become all the more sophisticated.

The 'most straunge and wonderfull herring' caught off the coast of Norway in 1597 had no immediate link to English fishermen, but was easily integrated into the conceptual framework of the monstrous fish. An anonymous English pamphlet described in some detail the depiction of two men armed with lances and swords that marked one side of the fish, and a set of strange characters, hieroglyphics, on the other. The author of the pamphlet nodded to the rhetoric of earlier stories, situating the herring within what he clearly regarded as an established tradition of God's merciful communication with his people 'by his wonderfull signes and tokens shewed in the heauens, the earth, or his other creatures' that were intended to induce the people to 'forsake their former wickedness'. Such calls and warnings had been part of God's intervention in the affairs of the world described in Genesis, and evidenced in the parting of the Red Sea, the destruction of Sodom, and the Flood. The tail of the herring carried the marks of two rods, a sure sign that sinful man would be subject to the correction of God. As the finger had written on the wall at Belshazzar's feast, so the herring had been marked by 'digitus dei' to 'figure forth' the need for repentance, and faith in the mercy of Christ (Doetecam 1598, pp. A2v, A3r; Walsham 1999, p. 167). The appearance of the herring, and the meaning attributed to it by the author of the tract exploited and cemented the connection between signs in the bodies of animals and the providential wisdom and benevolence of God, and between such calls for repentance and the broader genre of natural history. 


\section{3. 'Openly Shewed and Sene Aswell of Englishe Men': Witnessing and Describing Wonders of Nature}

The desire to interpret the appearance of irregularities in nature was not unique to the English context. For the Calvinist preacher Pierre Viret, a providentialism that was anchored in natural theology was a form of spiritual medicine. Just as the nourishing and medicinal properties of fish could cure the body of its physical ailments, so a moralised narrative of an unnatural fish that could recover the soul. Under the heading 'Des Poissons \& divers animaux de la mer \& des merveilles de Dieu en iceux \& des profits qui en revienent [sic] aux hommes', Viret concluded his Instruction Chrétienne with a catalogue of monstrous fish that served a dual purpose as a natural history, and as a repository of anecdotes and exempla that could be used to illustrate providential preaching. The 'wonders of God' exhibited in the fish and animals of the sea brought profit to men by inculcating a fear of God's anger and promise of redemption manifested in nature (Viret 1564, p. 162; Garrod 2012, p. 227; Cazenave 1979; Clesse 2018; Linder 1966). However, the particular positioning of unnatural sea creatures within the schema of English Protestant providentialism should remind us of the need to reflect upon the relationship between event, author, and the physical and mental context in which such interpretations fermented. The close association between event, text and context has been described in detail by Azzolini (2017). But the monstrous fish that graced the religious landscape of Elizabethan England were neither explicitly nor exclusively English; rather, their history reflected the willingness and determination of English authors to appropriate and manipulate events outside their immediate context in such a way that their 'message' spoke to a particular set of priorities. The context in which the author lived clearly shaped the writing of the text, but often in a way that paid much less heed to the context in which the events originally unfolded. The protagonists in the story might have been from Holland, or from Norway, but God's message, embodied in unnatural fish, was evidently intended for an English audience. As Norman Jones has argued, the appeal of that approach was anchored in the political and religious climate of late sixteenth-century England, and the popularity of religious rhetoric that personalised misfortune and then presented an individual and collective solution in the form of repentance as a response to evidence of God's wrath (Jones 1993, introduction).

However dominant this overarching message, narratives of providential intervention in nature were still anchored in extraordinarily detailed descriptions of the particular event. Such an approach served to cement the general assertion of 'truth' that permeated the narrative, but we can also perceive here an instructive point of intersection between the religious and moral language used to describe the 'wondrous' event, and the encyclopaedic detail that characterised the less evangelical and sermonising descriptions of similar creatures in early modern natural histories. The scale and texture of Gesner's presentation of all available information relating to specific animals, for example, is not entirely removed from the approach taken by the authors of popular pamphlets that threatened the judgement of God upon the sinful reader.

In the 1566 pamphlet discussed above, The Discription of a rare or rather monstrous fishe taken on the east coast of Holland (Anonymous 1566), the author was clearly determined to provide his reader with as much detail as was available to support his interpretation of events. The presence of witnesses to the discovery of the fish was therefore an important part of the account. Sceptical readers might be reassured to learn that the 'noble persons' of Flanders had seen the fish, and assiduous in their inspection of its form, had 'plucked of his skales ... kepes them for a shew.' In case the testimony of such eye witnesses was insufficient, the author of the tract observed that three weeks after its discovery, the fish had been taken to Antwerp where it was 'openly shewed and sene aswell of Englishe men.' The appearance of the fish was described in some detail, and in a language that was culturally and contextually meaningful. The fins were covered in 'hard skales in forme much like the beggers disshes, which in that Contrie they were wont to weare in skoffe \& derision.' Its eyes were described as 'like an owle' and its tail 'fower cornered like to a priestes Cap.' The providential was here mapped onto the natural and the material, enabling the imagery of the four-cornered biretta to impart a message that was rather more polemical and anti-Catholic in its tone. 
Again, we can observe marked similarities in the content and tone of the 1569 pamphlet describing the 'marvellous straunge fishe' that had destroyed the nets of the fishermen who encountered it. The narrative in this pamphlet was more firmly tied to English experience; the fish had been captured by 'certayne English Fissher men' who had been fishing for mackerel between Calais and Dover. In order to lend credibility to the tale, those on board the vessel had used 'such instruements, ingins, \& thinges that they had: made such shift that they tooke this straung Fishe. And vppon fridaye the morowe after brought it vpp to Billynges gate in London', where it was seen by an indeterminate 'many' who marvelled at its shape and size. The appearance of the fish was described in detail, and the textual account accompanied by an illustration. The fish was some seventeen feet in length, and three feet broad, 'and in compas about the bodie .vi. foote.' It had a round snout, 'short' head, eyes 'as big as a horses' and three 'ranckes of teeth [...] maruaylous sharpe and very short.' Once the body was cut open, the heart and liver were revealed to be as large as that of an ox. For the curious or sceptical reader, the author presented an enticement to see the remains of the body, which were displayed in London at the Red Lion, Fleet Street.

The language of witnesses and evidence used in these two pamphlets was not limited to the religious rhetoric of Elizabethan England. Rather, it permeated a broad range of providential narratives including A most strange and true report of a monsterous fish (P.G. 1604) that described the appearance of a creature that was half fish, half woman, in 1604 off the coast at Pendine, Carmarthenshire. The author was quick to relate this event to earlier accounts of God's intervention in nature, noting similar instances reported in the past, including monstrous births, strange beasts, whales and strange fishes, fiery dragons, sights in the air, all of which were 'tokens' of the majesty of God. A detailed account was provided of the Pendine 'mermaid' along with a list of witnesses who would all vouch for the authenticity of the written account. The Pendine mermaid slotted readily into the framework that we have observed in the pamphlet literature of the 1560s. In 1781, a second hybrid creature was reported to have been sighted, this time at Linney Head. H.M. Vaughan, who noted the similarities between the two accounts of the sightings, observed that both were well documented, and witnessed. 'What did all these people see?' he pondered. 'Was it a dugong, or manatee, or other visitors from tropical seas, or was it, as the picture seems to suggest, an unusually large seal? The chief hindrance to an acceptance of these naturalistic explanations ariose from the very human hands and arms attributed to the creature. A lively imagination would need to be called into play to convert a seal's paddles into the 'two fayre handes' shown in the drawing. But for these features Vaughan concluded, it would seem that the Pendine creature was a seal, and the pamphlet that described it based upon an 'exaggerated and imaginative account', distorted in its retelling and recontextualising in late eighteenth century Linney Head. But in both cases, a detailed natural history was intermingled with a language of God's majesty and wrath in the natural world, alongside personal testimony, local memory, and an evolving religious culture.

In the four examples above, we can see clearly the importance attached to detailed description and reference to sources and witnesses in the construction of a providential history of the natural world. Observation — what was seen with the eyes, and preferably first hand —was a necessary part of any plausible narrative of nature. A natural history, or a providential exampla, that was based upon the reading of texts, however careful or extensive, lacked the understanding and plausibility that could be gained only in the visual encounter. This encounter could take any number of forms; it was not necessary to encounter a creature in the living flesh in its own natural habitat; part of the drive to towards the collection of samples and specimens was fuelled by this curiosity and desire to 'see' in order to understand. Observation did not replace the written word, but it was becoming increasingly hard to provide an accurate representation of that which had a literary presence but no reliable witness. In addressing this issue, it is worth noting that the authors of providential polemic shared an approach and a language with those who were charting the course of natural history in early modern Europe. Two unusual sea-creatures found in the mid sixteenth century provide an example of this prominent positioning of the author's voice, personal testimony and the provenance 
of information in early modern natural histories, particularly nascent French icthyology. In 1531, a creature labelled the 'Sea Bishop' was reported to have been found in Poland, and a decade later, a half man, half fish 'sea monk', was discovered in the Øresund. In the printed descriptions of both creatures in the half-century that followed, we can observe the tendency for writers to repeat and embellish the information provided by their predecessors, in an attempt to present as much detail as possible of each creature. The encyclopaedic and cumulative quality of early modern natural history is abundantly clear, but the desire to anchor the description in the reality of personal observation and encounter is also evident. The repetition of these narratives suggests that such stories were ensured a broad cultural consumption, but the nature of that readership and reception could also shape the narrative itself.

The first detailed account of the Sea Monk was provided by the French ichthyologist Pierre Belon in the De Aquatilibus (1553). The creature was some eight feet long, covered in a monastic habit, with fins positioned mid body and at the tail, but with a black head, and human face and mouth. The creature lived for three days, and was capable of making sound, but not speech. Belon's description of the 'monacus piscis', was accompanied by an illustration which matched the verbal account (Figure 1). Several natural histories from the sixteenth and seventeenth century described the creature, incorporating detail from Belon's description, most notably Rondelet's Libri de Piscibus (1554) which much of Belon's original description, as well as an illustration of the Sea Monk (Figure 2). Rondelet's description, like that in most accounts, was derived from other printed works, and none of the authors claimed to have seen the Sea Monk in the flesh. In the French translation of his work, Belon's Sea Monk formed one part of a longer section devoted to unusual sea creatures and wonders, including the Sea Bishop, mermaids, sirens, and tritons. (Belon 1555) Belon also referred his readers to an entry in the Annals of Brabant in which was described a fish, wearing episcopal garb including a pontifical mitre, the so-called Sea Bishop. Again, Belon could not claim to have had a personal encounter with the Sea Bishop, but on this occasion it was possible to locate appropriate evidence based upon the observation of others, via the Annals. Belon was reluctant to argue for the veracity of the tale, but it is possible to see in this text the same layering of evidence that we observed in the English vernacular treatises describing providential sea creatures. The physical appearance of the Sea-Monk and Sea-Bishop certainly resonates with that in narratives within the broader genre of natural events that were imbued with a polemical and confessional purpose. In Rondelet's Latin text, we see a more detailed discussion of the Sea Bishop than that Belon's original summary, describing a creature that possessed the face of a man, with a shaven head, and a cloak that resembled a monastic cowl over its shoulders. The imagery, though, was consistent; the creature was not simply a deformed fish, but one that was intended to be read as a commentary upon monasticism and the Protestant reformation. Rondelet had not seen the creature first hand, but instead based his account upon an illustration received from Margaret, Queen of Navarre. Again, this identification of personal contacts and sources of information reflected a desire to present plausible and accurate evidence to support the textual description, but Rondelet was also ready to question the veracity of some of the details, warning that it was the way of men to 'embellish' something that was already wondrous (Figure 3). The claim that the Sea Bishop communicated with its human audience and pleaded to be returned to the sea, he suggested, pushed the story beyond the bounds of truth. (Rondelet 1554: 494). 


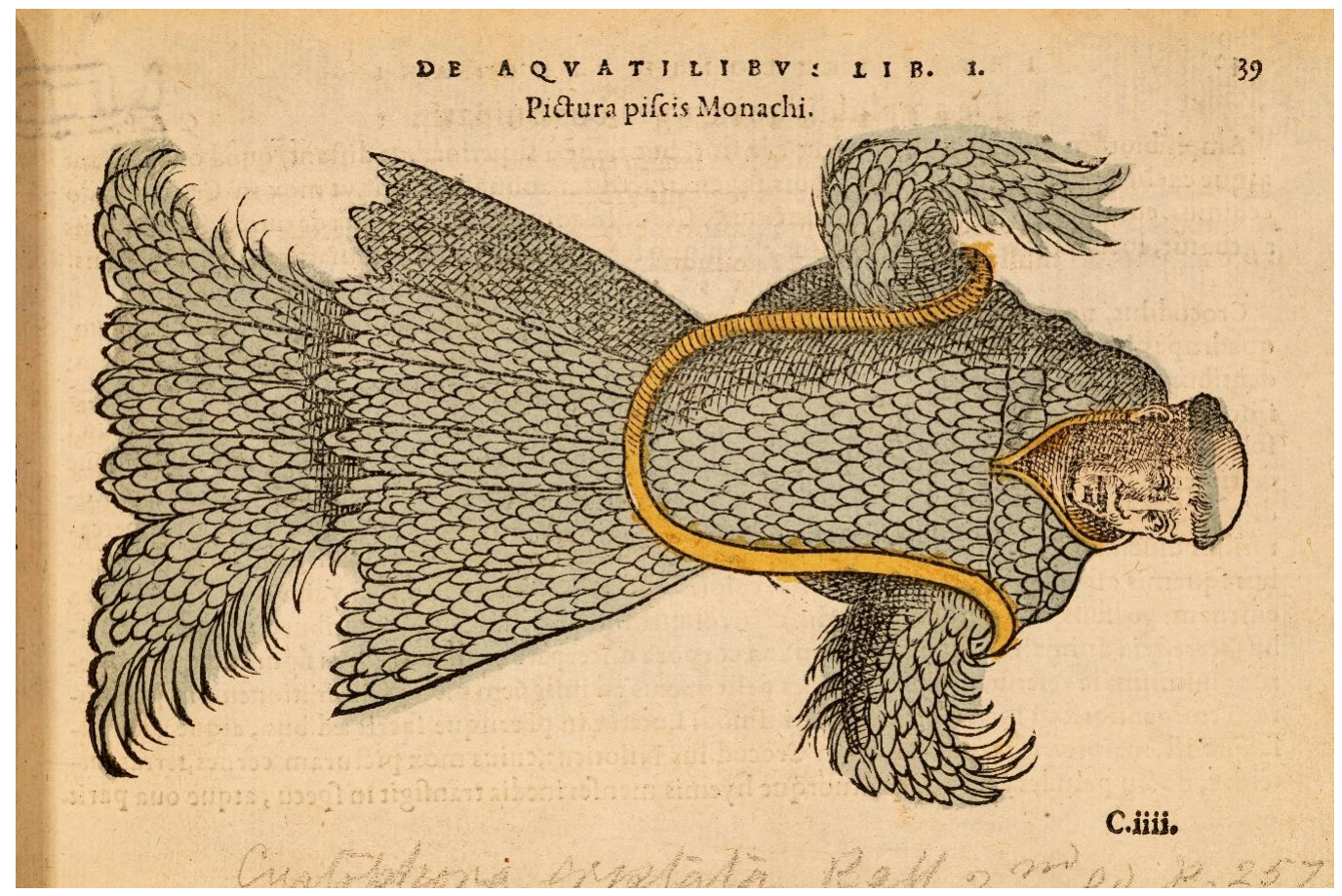

Figure 1. Belon, P. 1553. De Aquatilibus. cum [eï]conibus ad viuam ipsorum effigiem, quoad eius fieri potuit, expressis: Paris: Charles Estienne. Reproduced with kind permission of University of Reading Special Collections.

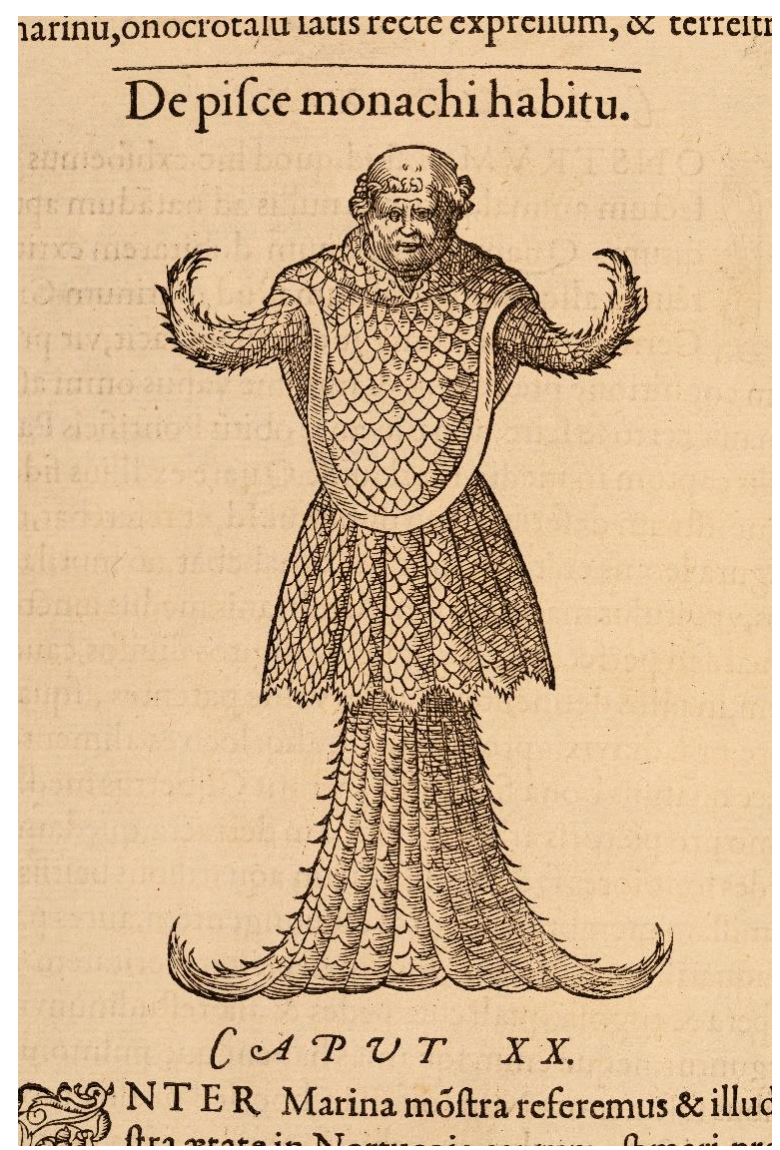

Figure 2. Rondelet, G. 1554. Libri de Piscibus Marinis. Lugduni: Apud Matthiam Bonhomme. Reproduced with kind permission of University of Reading Special Collections. 


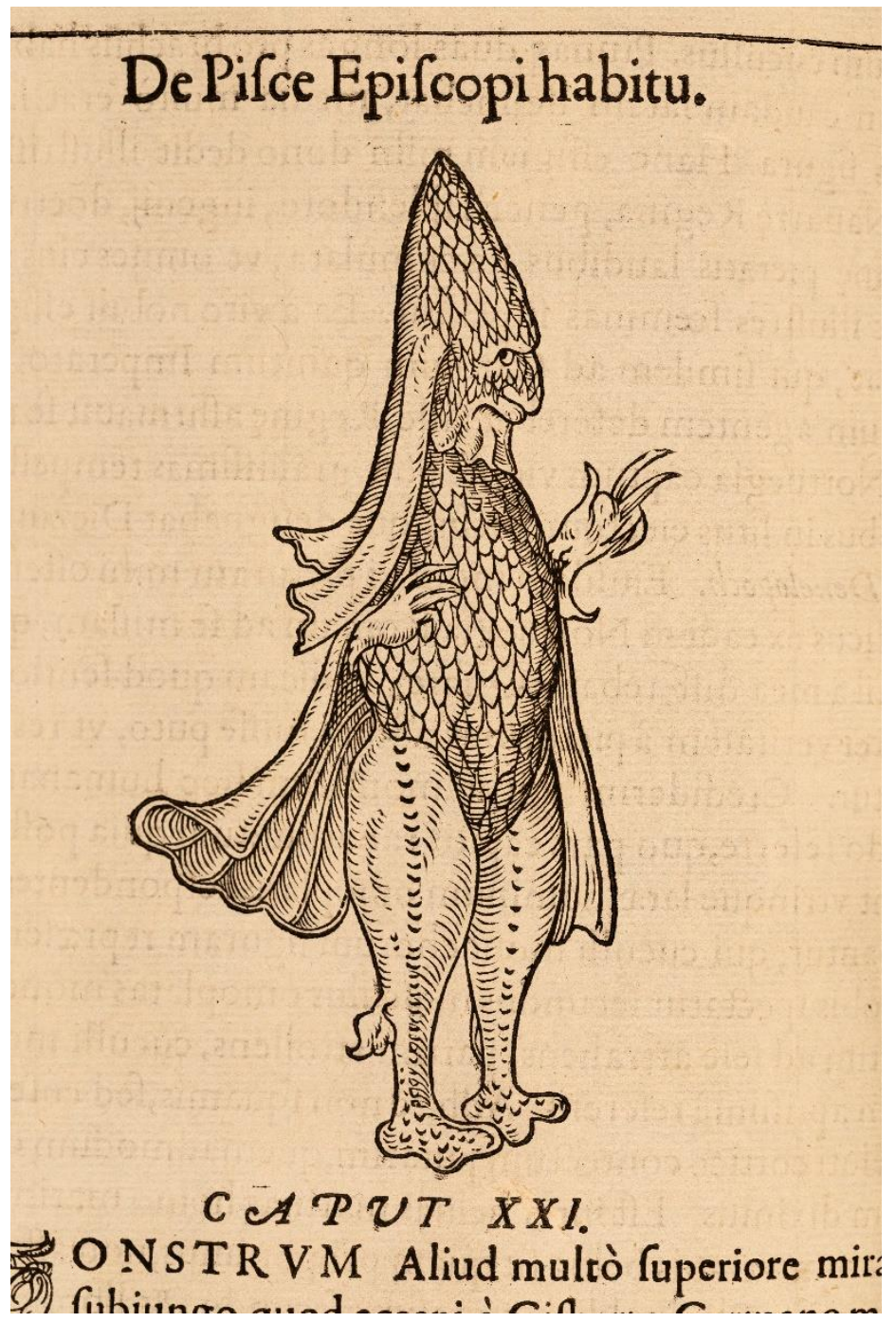

Figure 3. Rondelet, G. 1554. Libri de Piscibus Marinis. Lugduni: Apud Matthiam Bonhomme. Reproduced with kind permission of University of Reading Special Collections.

In Conrad Gesner's description, heavily informed by Belon and Rondelet, the providential meaning of the Sea Bishop was largely invisible. For Gesner, the value of the creature lay rather in its role as an example of the broader taxonomy of hybrid sea creatures. Gesner claimed to have augmented the account with additional evidence and personal testimony and the 'Wassermünch' ('ein Meerwunder einem München geleych') was highlighted as a discovery 'in our time', and open to validation by eye witnesses. The emphasis upon evidence, and particularly the evidence of the eyes, was in the foreground, and Gesner was swift to point out that his detailed description of the Sea-Bishop was the fruit of personal exchanges within the intellectual community of natural philosophers and historians. In the absence of personal observation, the authority of a network of correspondents was enough to persuade. But for Gesner, the desire to present all the evidence that was available for the authenticity of the Sea Bishop meant that the narrative was still anchored not in eye witness alone, but in the testimony of Boethius, who described a similar creature found in the Firth of Forth. Not only the eyes, but history and text demonstrated that the sea was richly capable of supporting monstrous creatures. It was clearly possible for multiple interpretations of the connections between religious truth and monstrous fish to co-exist within such models. Natural irregularities retained their function as a visible expression of God's anger with humanity, but the same creature could also possess a purpose that was anchored a more mechanical function and explanation. In the hands of the natural 
philosopher Paracelsus, for example, the Sea-Monk was easily explained as the progeny of a fish and a drowned monk (Szabo 2008; Gesner 1558, pp. 520-21; Magnus 1555, p. 729; Hendrikx 2017, 2018; Rackham 1967, p. 164; Paxton and Holland 2005; Mackenzie 2014; Pinon 1995; Blair 2010).

\section{4. 'Vera ea sit an non, nec affirm, nec refello': Truth and Fiction in the Natural World}

The enduring appeal of unnatural sea creatures can be attributed to the positioning of such narratives as a weapon in the polemical and pastoral literature of the European Reformation, and to the attractiveness of such examples as a means of pursuing a natural history of the oceans. The language and imagery in accounts of the Sea Monk and Sea Bishop made an overt visual and literary connection to debates over monasticism and its suppression, the existence and authority of the episcopacy, and the extent to which religious reformation could be seen to harness the providential approval of an interventionist deity. Rondelet's approach was more neutral than those provided in the pages of Reformation polemic; the comment vera ea sit an non, nec affirm, nec refello ('whether this is true or not, I do not affirm nor refute') suggested that the duty of natural history was to document rather than arbitrate in matters of religious meaning and authoritative testimony in the cataloguing of the created world (Rondelet 1554, p. 494). English vernacular broadsides that reported unusual occurrences in the natural world fuelled and satisfied an appetite for 'factual' accounts of the sensational that could be described as 'strange but true.' The intermingling of news, nature, and divine or supernatural agency created narratives that were constructed within a religious framework but treated as events of natural history (Shapiro 2000, pp. 88-89). Indeed, the very plasticity and multiple meanings of nature enabled phenomena such as the Sea Monk and Sea Bishop to occupy the realms of both natural occurrences and providential or miraculous intervention. But where the appearance of such creatures betrayed the intervention of the hands of men rather than the hand of God, that connection between animal and religion, created nature and the message of the Creator, became more tenuous. Natural histories and polemical treatises that collated rather than challenged the existence of wondrous creatures encouraged the proliferation of such narratives, and the expansion of the 'evidence' available to inform such narratives served to create and perpetuate an audience that consumed such information.

A common verbal and visual lexicon was used to describe animals in early modern natural histories. But that language was shaped as much by syncretism as by conscious separation from the precedents of the past. Belon, Rondelet, and Gesner provided detailed descriptions of mammals, reptiles, amphibians, insects, and marine life, informed by personal experience and the contributions of the community of like-minded students of nature. But the pages of these natural histories were replete with references to Scripture, Christian exempla, ancient natural histories, proverbs, pagan myths, letter and chronicles. The symbolism of the sacred certainly sat alongside the interrogation and documentation of nature in such texts, in a careful balancing of the 'vanity' of men's opinion against the veracity of God's word and value of canonical texts (Rondelet 1554, p. 494). Beasts, birds, fish and serpents were part of a rich kaleidoscope of natural knowledge that ranged from the theological to the zoological, and encompassed medicine, botany, philosophy, astronomy and geology. This complex picture of the natural world was perpetuated by each additional retelling. The rhythm of Christian writing on nature resounded with the voice of fables, folklore, and classical legend. The pages of Protestant providentialism, as Alexandra Walsham has shown, likewise contained much that was inherited from Aristotle, Cicero, Pliny and others, filtered through encyclopaedists like Isidore (Walsham 1999, 2011). Pliny's Natural History made a swift transition from written word to printed page in 1469, with more than fifty editions in print by the end of the seventeenth century. Those who described nature in its normality and in its wonders were still influenced by the same biblically based principle that had guided their forebears (Rom 1:20) that the created world was the visible work of the invisible God, and a means by which mankind might come to encounter the divine. It was, consciously, $a$ means and not the means; the word of God was written first in sacred scripture and secondarily in His physical creation, but this did not mean that the message of the Gospel could not be carved on a natural world hewn by the Creator. Such a principle was articulated succinctly by James Pilkington, 
bishop of Durham, in the assertion that 'I wa[n]t no bokes, for all the creatures of God are my bokes, \& I read \& learne his maiesty out of his creatures, as you do out of your bokes' (Pilkington 1562, sig.R6r). There was no conflict here between a knowledge of nature and a knowledge of God; indeed, it was often in evangelical zeal that an enthusiasm for the deeper understanding of nature had its roots (Walsham 2011, p. 339). In this context, theologically and pastorally inspired interpretations of nature as a record of God's providential intervention in the created world were fashioned into a rich tapestry of knowledge and meaning woven from natural histories. But the strength of that weave could be pushed to its limits when natural histories collided with religious texts, and where God's will appeared to be communicated not through natural irregularities, but through man-made signs and symbols, hybrid creatures that bore the mark of human creativity. The manipulation of nature in religious rhetoric had turned nature into a potent and profitable commodity, whether in satisfying curiosity, or providing comfort (Findlen 2002, pp. 301ff). The marvelous, the wondrous, and the curious not only invited a pastoral and providential interpretation, but also encouraged a more pragmatic form and view of creation, in which nature was bought and sold, fashioned and fabricated. Conrad Gesner, in his Historia Animalium (1558) made reference to 'apothecaries and others who usually dry rays and shape their skeletons into varied and wonderful forms for the ignorant', creating curiosities that could provoke fascination and fear in equal measure. Created by God, nature was reinvented by man, twisting the relationship between religion and the reading of the non-human as a form of faith.

The Jenny Haniver represents one of the most unusual examples of human manipulation of 'natural' animals and fish of the type that had once been regarded as conduits of the divine. Created from a guitar ray (elasmobranchii or perhaps teratological ray which had never reached full adult form) Jenny Hanivers were formed by curling the fins of the ray over its back, twisting the tail, and tightening the head behind the jaws to form a neck. Left in the sun, the shrinkage of the head forces the jaws forward into the shape of a snout, and the widened nostrils acquire the shape and position of eyes (Dance 1976). The process of creation was described in detail in Conrad Gesner's Historia Animalium, which attributed the existence of Jenny Hanivers to 'the vendors of medicines' and others who were 'accustomed to dry rays and fashion their skeletons into varied and wonderful shapes for the multitude. They also exhibit others which resemble the serpent or the winged dragon. [To make these] they bend the body [of the ray] distort the head and mouth and cut away other parts. They take away the forward parts of the sides and raise up the remainders that they may simulate wings and other parts they modify as they wish.' (Gesner 1558, book 4, p.945).

Gesner's account of the creation of the Jenny Haniver was heavily influenced by text and imagery in Pierre Belon's earlier De Aquatilibus (1553). Here, the specimen depicted resembles a ray, but a substantial portion of the wings have been cut, and the shape of the head altered leaving a pointed snout that protrudes at an angle. The mouth is stretched open, two tooth plates are visible, and the nostrils resemble eyes (Figure 4). However, the woodcut itself shows signs of modification, with the tail of another ray still visible behind the main part of the modified fish (Gudger 1934). The fish is presented alongside a description of other rays, but although both the image and the ray have clearly been tampered with, Belon does not explicitly acknowledge this in the accompanying text. Instead, he presents a detailed account of a monstrous fish that is capable of leaping from the water to catch its prey, and smells and tastes sufficiently unpleasant that human consumption would be ill advised (Belon 1553, p. 97). Belon's altered ray was widely copied, re-appearing not only in Gesner's Historia Animalium, but also in Rondelet's work, Ambroise Paré Monsters and Marvels (1579) and in Aldrovandi's De Piscibus Libri V (Aldrovandi 1613: 437). Gesner is direct in his assertion that such creatures were the invention of man, made to inspire wonder, although admitted that at first he did not recognise the animal as a fake. His introduction to the ray came via an apothecary, who presented the fish to Gesner as a natural phenomenon. 'Ordinary people are very much impressed with these things', Gesner complained, suggesting that a more circumspect approach would be appropriate. His description and image of the modified ray, derived from Belon, was reproduced two years later in an abridged version of the Nomenclator Aquatilium Animantium (Gesner 1560, p. 139). Paré 's account was 
likewise informed by Belon's description, although by now the modified fish had acquired a more detailed form. Paré described a fish that was 'terrible and marvellous to see', some four feet wide, with a large head, two sets of eyes, two ears, a green fleshy snout, two sets of wings, five openings on each side of the body and a long tail (Paré 1573). Successive descriptions imposed their own modifications upon the ray, culminating in Ulysse Aldrovandi's remarkably elaborate representation of the creature (Figures 5 and 6). Here, the ray has acquired two wings, the tail spines have been removed, and five round apertures (created from gill slits) added on each side. The modified head depicted by Belon and Rondelet has been further distorted to create a more prominent lower lip, a hairy upper lip, and two staring eyes framed by eyebrows. Aldrovandi was an enthusiastic collector of aquatic specimens and drawings, including several Jenny Hanivers that formed the basis of his description of their various forms in the De Piscibus. He was certainly much more explicit than Belon or Rondelet in asserting that the ray was a man-made wonder: 'Showmen fashion diverse-shaped figures from dried rays and foist these on the ignorant.' (Aldrovandi 1640, p. 315).

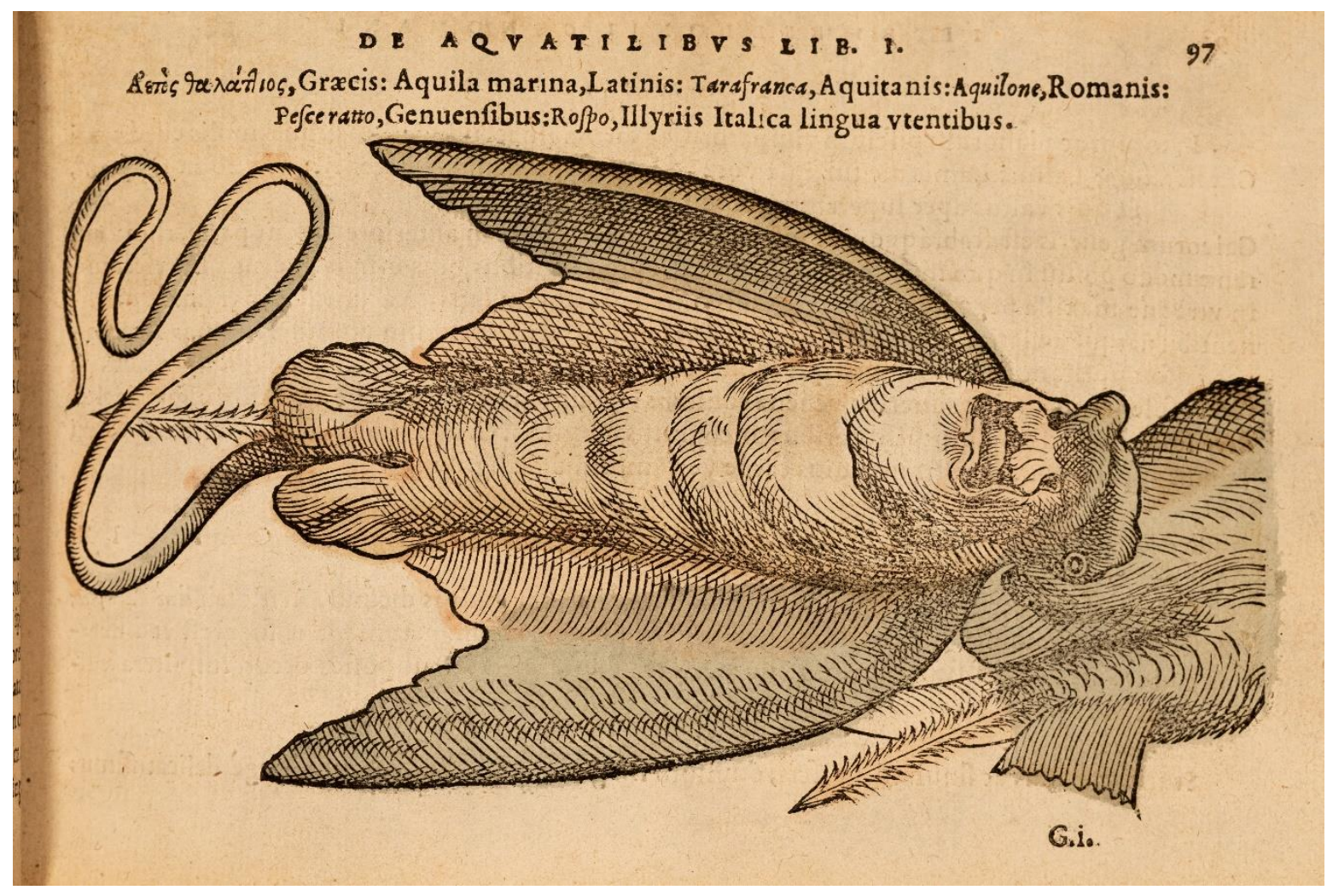

Figure 4. Belon, P. 1553. De Aquatilibus. cum [ei]]conibus ad viuam ipsorum effigiem, quoad eius fieri potuit, expressis. Paris: Charles Estienne. Reproduced with kind permission of University of Reading Special Collections. 


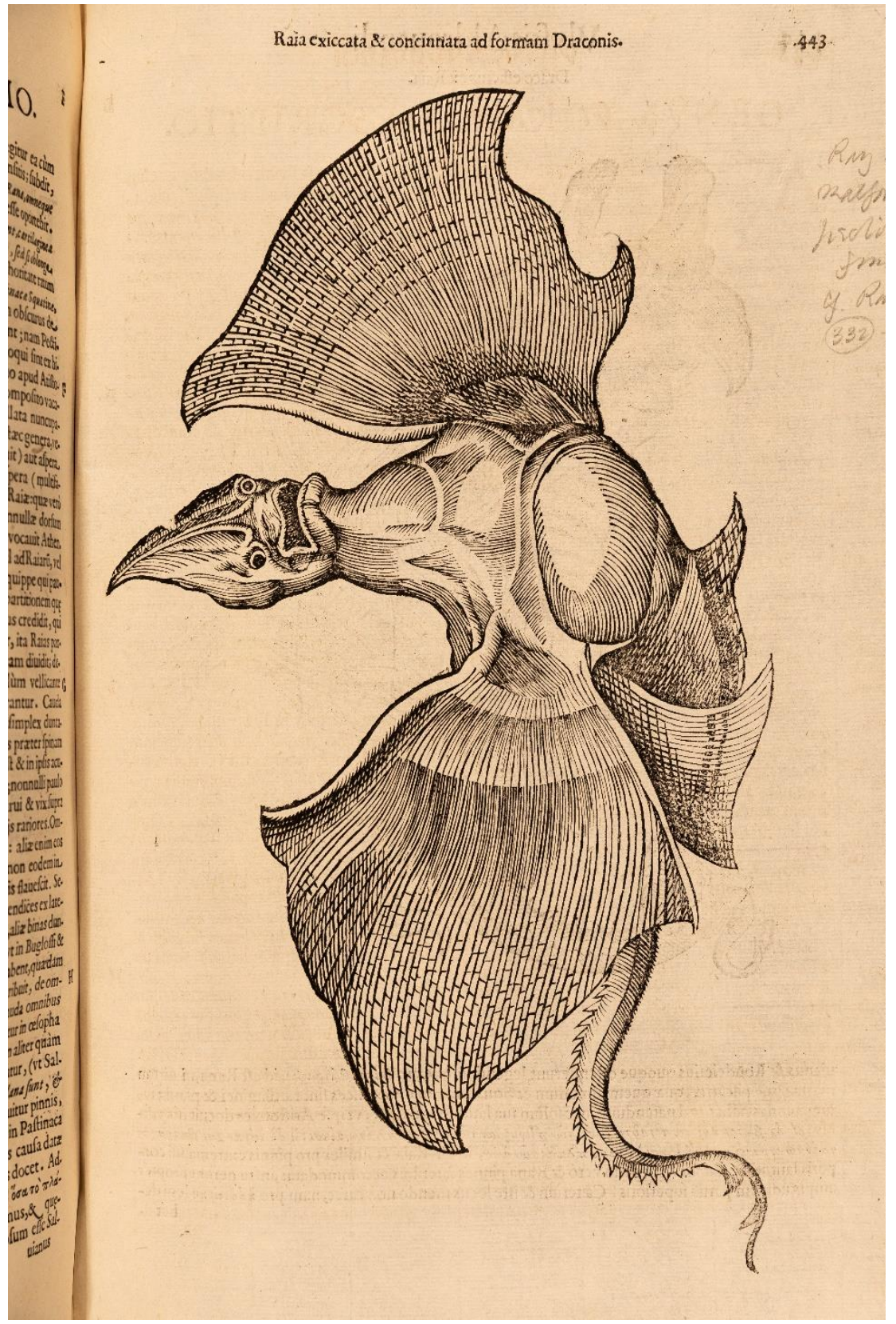

Figure 5. Aldrovandi, U. 1613. Vlyssis Aldrovandi philosophi et medici Bononiensis de piscibvs libri $V$ et de cetis lib. Vnvs. Bonn: Apud Bellagambam. Reproduced with kind permission of University of Reading Special Collections. 


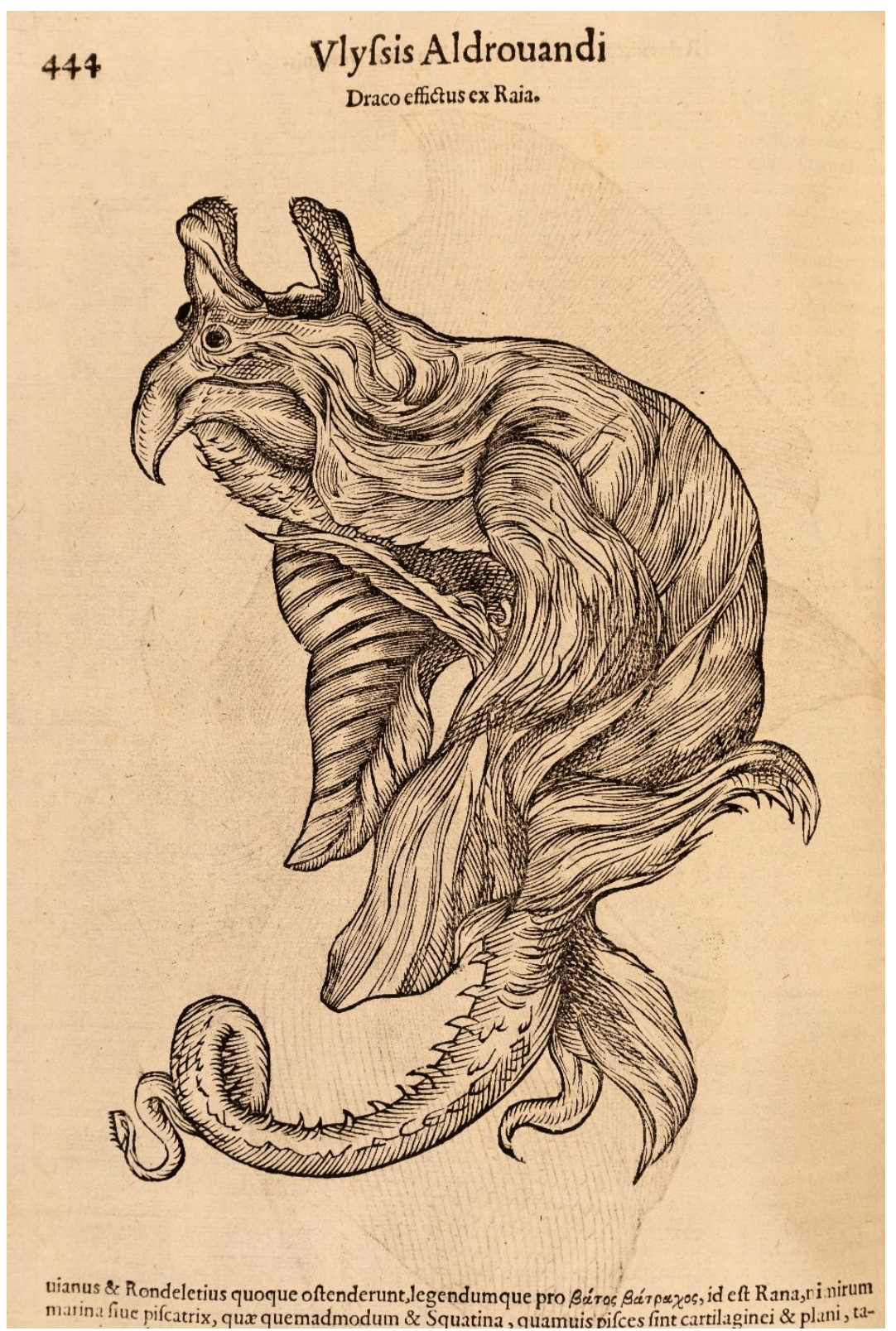

Figure 6. Aldrovandi, U. 1613. Vlyssis Aldrovandi philosophi et medici Bononiensis de piscibvs libri V et de cetis lib. Vnvs. Bonn: Apud Bellagambam. Reproduced with kind permission of University of Reading Special Collections.

\section{Conclusions}

Wonders and irregularities in the animal realm, not just the tangible and 'real', were a key and consistent part of the way in which early modern Europeans envisioned themselves and the natural world (Daston and Park 1998). Widespread dissemination of 'true' narratives of unnatural fish in providential literature and natural histories may well have fuelled suspicions that such creatures were frauds rather than fact, not least when, in the case of Jenny Hanivers, the workmanship was clearly not that of God. But the prism of physical experience did not occlude assumptions about the ongoing influence of the hand of God in creation and divine interventions in the world, or immediately undermine the reality of creatures described in the pages of earlier natural histories and authoritative sources. In fact, stories about the presence of the unnatural in nature had an enduring appeal precisely because such exempla had the ability to cross the permeable boundaries between religious and natural 
explanations. Such narratives could clearly become the stuff of chatter and gossip, and enthusiasm for displays of monstrous fish in the taverns of London perhaps had less to do with edification than with entertainment. But Alexandra Walsham rightly warns against the dangers of exaggerating the extent to which natural prodigies and providences were demythologised in the early modern period. Even divorced from the threatening associations with the wages of sin, unnatural fish and distorted animals could still present evidence of the power of nature and the God that created it. Natural history had not yet lost its connection to theology, and its use was still shaped by the malleability of its form and language, and its position as a potent and pervasive presence in early modern print culture (Walsham 1999; Thomas 1983, chp. 2; Daston and Park 1981, pp. 43-54; Kusukawa 1995; Ashworth 1990; Clark 1999, p. 11; Hendrikx 2018).

As a result, throughout our period, the interpretation of unusual sea-life was shaped by a language which communicated a view of nature that was both moralised and mechanical, an approach to the natural world in which the providential and the pragmatic continued to share textual space in histories of nature. Even without an overt assumption that animals and sea creatures were a conduit for God's communication with mankind in moral terms, or divine interventions that addressed the question of sin and redemption, both consistencies and contradictions are equally evident in the histories of nature discussed above. The social and cultural context in which such histories were written, throughout our period, exerted a profound influence over both content and shape. Sixteenth-century narratives of nature were deeply anchored in the accounts of nature presented by Pliny and the medieval bestiaries, but they were also texts in which the voice of the author, and the people that he encountered, loomed large, with oral testimony punctuating the descriptions of nature in every section. The plurality of historia of nature in its multiple forms exhibited a syncretism in which continuity and change were complementary rather than competing (Walsham 1999; Mackenzie 2014; Ogilvie 2006; Glardon 2006). The proponents of Protestant providentialism and natural science were equally willing and able to present and interpret the evidence before them in a variety of ways, shaped by a shared interest in the description of the natural and the 'wonderful', a focus on evidence rather than causation, and desire to see in 'every living beast being a word, every kind [ ... ] a sentence' that created, and was created by, the human reading of the book of nature.

Funding: The APC was funded by The University of Reading.

Conflicts of Interest: The author declares no conflict of interest.

\section{References}

Aldrovandi, Ulisse. 1613. Vlyssis Aldrovandi philosophi et medici Bononiensis de piscibvs libri V et de cetis lib. Vnvs. Bonn: Apud Bellagambam.

Aldrovandi, Ulisse. 1640. Draco ex Raia effictus. In Opera omnia. X: Serpentum et draconum historiae libri duo. Bologna: N. Tebaldini.

Anonymous. 1566. The Discription of a Rare or Rather Most Monstrous Fishe Taken on the East Cost of Holland the. XVII. of Nouember, anno 1566 The Workes of God How Great and Straunge They Be a Picture Plaine behold Heare May You See. London: Thomas Purfoot.

Ashworth, William B. 1990. Natural History and the Emblematic World View. In Reappraisals of the Scientific Revolution. Edited by David C. Lindberg and Robert S. Westman. Cambridge: CUP.

Azzolini, Monica. 2017. Talking of animals: Whales, ambergris, and the circulation of knowledge in seventeenth-century Rome. Renaissance Studies 31: 297-318. [CrossRef]

Belon, Pierre. 1553. De Aquatilibus. cum [eï]conibus ad viuam ipsorum effigiem, quoad eius fieri potuit, expressis: ad amplissimum cardinalem Castillionœum. Paris: Charles Estienne.

Belon, Pierre. 1555. La nature et diversité des poissons: avec leurs pourtraicts, représentez au plus près du naturel. Paris: Charles Etienne.

Blair, Ann. 2010. Too Much to Know. Managing Scholarly Information before the Modern Age. New Haven: Yale UP.

Brammall, Kathryn. 1996. Monstrous Metamorphosis: Nature, Morality, and the Rhetoric of Monstrosity in Tudor England. The Sixteenth Century Journal 27: 3-21. [CrossRef] 
C.R. 1569. The True Discription of This Marueilous Straunge Fishe, Whiche Was Taken on Thursday Was Sennight, the XVI. Day of June, This Present Month, in the Yeare of Our Lord God. M.D.LX.ix. London: Thomas Colwell.

Cazenave, Annie. 1979. Monstres et merveilles. Ethnologie Française 9: 235-56. Available online: http: //www.jstor.org/stable/40988545 (accessed on 18 March 2019).

Clair, Colin. 1967. Unnatural History. An Illustrated Bestiary. London: Abelard-Schuman.

Clark, Stuart. 1999. Thinking with Demons. The Idea of Witchcraft in Early Modern Europe. Oxford: OUP.

Clesse, Grégory. 2018. Un compilateur en eaux (in-)connues: Thomas de Cantimpré et la faune aquatique du nord-ouest de l'Europe. Anthropozoologica 53: 87-97. [CrossRef]

Dal Prete, Ivano. 2014. 'Being the World Eternal'. The Age of the Earth in Renaissance Italy". ISIS 105: $292-317$. [CrossRef] [PubMed]

Dance, S. Peter. 1976. Animal Fakes and Frauds. Maidenhead: Sampson Low.

Daston, Lorraine. 2017. The history of science and the history of knowledge. KNOW: A Journal on the Formation of Knowledge 1: 131-54. [CrossRef]

Daston, Lorraine, and Katharine Park. 1981. Unnatural Conceptions: The Study of Monsters in Sixteenth- and Seventeenth-Century France and England. Past E Present 92: 20-54.

Daston, Lorraine, and Katharine Park. 1998. Wonders and the Order of Nature 1150-1750. New York: Zone Books.

Doetecam, Jan van. 1598. A Most Strange and Wonderfull Herring Taken on the 26. Day of Nouember 1597, Neere Vnto Drenton Sometime the Old and Chiefe Cittie of the Kingdome of Norway. Hauing on the One Side the Picture of Two Armed Men Fighting, and on the Other Most Strange Characters, as in the Picture Is Here Expressed. First Printed in Dutch at Roterdam by Ian van Doetecam. And Now Translated into English, Taken on the 26. Day of November 1597 ... . London: Imprinted by [J. Windet for] Iohn Wolfe.

Field, Judith, and Frank James, eds. 1997. Renaissance and Revolution: Humanists, Scholars, Craftsmen, and Natural Philosophers in Early Modern Europe. Cambridge: Cambridge University Press.

Findlen, Paula. 1994. Possessing Nature. Museums, Collecting, and Scientific Culture in Early Modern Italy. Berkeley: University of California Press.

Findlen, Paula. 2002. Inventing Nature: Commerce, Art and Science in Early Modern Cabinets of Curiosities. In Merchants \& Marvels: Commerce, Science and Art in Early Modern Europe. Edited by Paula Findlen and Pamela H. Smith. New York: Routledge, pp. 297-323.

Flore, Nora. 2000. Animals in the Middle Ages. London and New York: Routledge.

Fudge, Erica. 2000. Introduction to special issues: Reading animals. Worldview 4: 101-13. [CrossRef]

Fudge, Erica. 2002. A left-handed blow: Writing the history of animals. In Representing animals. Theories of Contemporary Culture. Bloomington: Indiana University Press, pp. 3-18. ISBN 9780253215512.

Garrod, Raphaële. 2012. On Fish: Natural History as Spiritual materia medica: Calvinist Pastoralism in Pierre Viret's Instruction Chrestienne (1564). Perspectives on Science 20: 227-45. [CrossRef]

Gesner, Conrad. 1558. Historia Animalium. Zürich: Froschauer.

Gesner, Conrad. 1560. Nomenclator aquatilium animantium icones animalium aquitilium in mari et dulcibus aquis degentium. Zürich: Froschauer.

Glardon, Philippe. 2006. L'Histoire naturelle du XVIe siècle: Historiographie, methodologie, et perspectives. Gesnerus 63: 280-98. [PubMed]

Gould, Stephen Jay. 2004. Father Athanasius on the Isthmus of a Middle State. Understanding Kircher's Paleontology. In Athanasius Kircher: The Last Man Who Knew Everything. Edited by P. Findlen. New York and London: Routledge, pp. 207-38.

Gudger, Eugene. 1934. Jenny Hanivers, Dragons and Basilisks in the Old Natural History Books and in Modern Times. The Scientific Monthly 38: 511-23. Available online: http://www.jstor.org/stable/15490 (accessed on 19 February 2019).

Hendrikx, Sophia. 2017. Ichthyology and Emblematics in Conrad Gesner's Historia piscium and Joachim Camerarius the Younger's Symbola et Emblemata. In Emblems and the Natural World. Leiden: Brill. [CrossRef]

Hendrikx, Sophia. 2018. Monstrosities from the Sea. Taxonomy and tradition in Conrad Gessner's (1516-1565) discussion of cetaceans and sea-monsters. Anthropozoologica 53: 123-37. [CrossRef]

Jardine, Nicholas, James A. Secord, and Emma C. Spary. 1996. Cultures of Natural History. Cambridge and New York: Cambridge University Press.

Jones, Norman. 1993. The Birth of the Elizabethan Age. England in the 1560s. Cambridge: Blackwell. 
Kelly, Donald R., ed. 1997. History and the Disciplines: The Reclassification of Knowledge in Early Modern Europe. Rochester: University of Rochester Press.

Kusukawa, Sachiko. 1995. The Transformation of Natural Philosophy: The Case of Philip Melanchthon (Ideas in Context). Cambridge: Cambridge University Press. [CrossRef]

Kusukawa, Sachiko, and Ian Maclean, eds. 2006. Transmitting Knowledge: Words, Images, and Instruments in Early Modern Europe. Oxford and New York: Oxford University Press.

Linder, Robert. 1966. Pierre Viret and the Sixteenth-Century French Protestant Revolutionary Tradition. The Journal of Modern History 38: 125-37. Available online: http://www.jstor.org/stable/1879030 (accessed on 19 February 2019).

Mackenzie, Louisa. 2014. Guillaume Rondelet's Sea-Monsters and Bruno Latour's Modern Constitution. In Animals and Early Modern Identity. Edited by Pia Cuneo. Burlington: Ashgate, pp. 329-49.

Magnus, O. 1555. Historia de Gentibus Septentrionalibus earumque diversis statibus, conditionibus, moribus, ritibus, superstitionibus, disciplinis, exercitiis, regimine, victu, bellis, structuris, instrumentis, ac mineris metallicis, $\mathcal{E}$ rebus mirabilibus, necnon uniuersis penè animalibus in Septentrione degentibus, eorumq[ue] natura. Rome: apud Ioannem Mariam de Viottis Parmensem.

McHam, Sarah Blake. 2013. Pliny and the Artistic Culture of the Italian Renaissance. The Legacy of the 'Natural History'. New Haven: Yale University Press.

Muller-Wille, Staffan, and Isabelle Charmantier. 2012. Natural history and information overload: The case of Linnaeus. Studies in History and Philosophy of Science Part C: Studies in History and Philosophy of Biological and Biomedical Sciences 43: 4-15. [CrossRef] [PubMed]

Mulsow, Martin. 2005. Antiquarianism and Idolatry. The Historia of Religions in the Seventeenth Century. In Historia: Empiricism and Erudition in Early Modern Europe. Edited by Gianna Pomata and Nancy G. Siraisi. Cambridge: MIT Press, pp. 181-210.

Ogilvie, Brian. 2005. Natural History, Ethics, and Physico-Theology. In Historia: Empiricism and Erudition in Early Modern Europe. Edited by Gianna Pomata and Nancy G. Siraisi. Cambridge: MIT Press, pp. 75-104.

Ogilvie, Brian. 2006. The Science of Describing: Natural History in Renaissance Europe. Chicago: University of Chicago Press.

P.G. 1604. A Most Strange and True Report of a Monsterous Fish, Who Appeared in the Forme of a Woman, from Her Waste Vpwards. London: W.B.

Paré, A. 1573. Des monstres et des prodigies. Paris: André Wechel.

Paxton, Charles G., and R. Holland. 2005. Was Steenstrup right? A new interpretation of the 16th century sea monk of the Øresund. Steenstrupia 29: 39-47.

Pilkington, James. 1562. Aggeus and Abdias Prophetes the One Corrected, the Other Newly Added, and Both at Large Declared. London: William Seres.

Pinon, Laurent. 1995. Livres de Zoologie de la Renaissance:une Anthologie. Paris: Klincksieck.

Pinon, Laurent. 2005. Conrad Gessner and the Historical Depth of Renaissance Natural History. In Historia: Empiricism and Erudition in Early Modern Europe. Edited by Gianna Pomata and Nancy G. Siraisi. Cambridge: MIT Press, pp. 241-68.

Pomata, Gianna, and Nancy G. Siraisi. 2005. Historia: Empiricism and Erudition in Early Modern Europe. Cambridge: MIT Press.

Rackham, H. 1967. Pliny, Natural History. Cambridge: Harvard UP.

Rondelet, Gulielmi. 1554. Libri de Piscibus Marinis. Lugduni: Apud Matthiam Bonhomme.

Shapiro, Barbara. 2000. A Culture of Fact. England 1550-1720. Ithaca: Cornell University Press.

Smith, Norman R. 1980. Portent Lore and Medieval Popular Culture. The Journal of Popular Culture 14: 47-59. [CrossRef]

Szabo, Vicki E. 2008. Monstrous Fishes and the Mead-Dark Sea: Whaling in the Medieval North Atlantic. Leiden: Brill. Thomas, Keith. 1983. Man and the Natural World. Changing Attitudes in England 1500-1800. London: Allen Lane.

Topsell, Edward. 1658. The History of Four-Footed Beasts and Serpents: Describing at Large Their True and Lively Figure, Their Several Names, Conditions, Kinds, Virtues (Both Natural and Medicinal) Countries of Their Breed, Their Love and Hatred to Mankind, and the Wonderful Work of God in Their Creation, Preservation, and Destruction. London: G. Sawbridge.

Viret, Pierre. 1564. Instruction Chrétienne. Geneva: Jean Rivery. 
Walsham, Alexandra. 1999. Vox Piscis: Or The Book-Fish: Providence and the Uses of the Reformation past in Caroline Cambridge. The English Historical Review 114: 574-606. Available online: http://www.jstor.org/ stable/580383 (accessed on 19 February 2019).

Walsham, Alexandra. 2000. Providence in Early Modern England. Oxford: OUP.

Walsham, Alexandra. 2011. The Reformation of the Landscape Religion, Identity, and Memory in Early Modern Britain and Ireland. Oxford: OUP.

(c)

(C) 2019 by the author. Licensee MDPI, Basel, Switzerland. This article is an open access article distributed under the terms and conditions of the Creative Commons Attribution (CC BY) license (http://creativecommons.org/licenses/by/4.0/). 